\title{
Investigation of Heavy Metal Sources on Railways: Ballast Layer and Herbicides
}

\author{
Alla Samarska ${ }^{1 *}$, Yuliia Zelenko', Oleksandr Kovrov ${ }^{2}$ \\ 1 Department of Chemistry and Engineering Ecology, Academician V. Lazarian Dnipro National University of \\ Railway Transport, Lazarian St., 2, Dnipro, 49010, Ukraine \\ 2 Department of Ecology and Environmental Technologies, Dnipro University of Technology, Dmytro \\ Yavornytskyi ave., 19, Dnipro, 49005, Ukraine \\ * Corresponding author's e-mail: samarskaya.av@gmail.com
}

\begin{abstract}
Railway operation can result in the significant environment contamination with heavy metals. The aim of the study was to broaden the knowledge about the railway transport as a source of heavy metals. Railway ballast stones and herbicides were chosen as the objects of the research since these contamination sources on railways are hardly investigated. The location of sampling the ballast stones was a passenger station, which is characterized by the high traffic intensity. The three most common glyphosate-based herbicides and two combination system herbicides of burn-down with other active agents were chosen for the analysis. The heavy metal content in the railway ballast stones was detected by means of XRF, in the herbicides - by means of MP-AES. The railway ballast stones did not contain a sufficient amount of $\mathrm{Cd}, \mathrm{Co}, \mathrm{Mo}, \mathrm{Pd}, \mathrm{Sn}$ and $\mathrm{W}$ for detection. $\mathrm{Pb}$ and As were detected at the low concentration of less than $35 \mathrm{ppm}$ only in several samples. The research results showed that the investigated railway ballast contained a significant amount of $\mathrm{Fe}, \mathrm{Mn}, \mathrm{Cu}, \mathrm{Cr}$ and Ni. According to the absolute content of $\mathrm{HMs}$ in the contaminated ballast layer, they can be arranged in the following sequence: $\mathrm{Fe}>\mathrm{Mn}>\mathrm{Cu}>\mathrm{Cr}>\mathrm{Ni}>\mathrm{Zn}>$ $\mathrm{Pb}>$ As. The content of $\mathrm{Fe}$ in the contaminated ballast stones was strongly correlated with that of $\mathrm{Ni}(\mathrm{r}=0.972)$, $\mathrm{Cr}(\mathrm{r}=0.954)$ and $\mathrm{Mn}(\mathrm{r}=0.943)$. These metals are components of the railway steel. Therefore, their source can be the abrasion of rails and wheels. All the investigated herbicides contained $\mathrm{Cd}, \mathrm{Co}, \mathrm{Cr}, \mathrm{Cu}, \mathrm{Fe}, \mathrm{Mn}, \mathrm{Ni}, \mathrm{Pb}$ and $\mathrm{Zn}$. The highest content of $\mathrm{Cd}, \mathrm{Cr}, \mathrm{Ni}$ and $\mathrm{Pb}$ was detected in the "Anti field bindweed" herbicide, which can be related to its complicated composition. Compared to the heavy metal content in the ballast stones, the herbicides can be considered a negligible source of these pollutants.
\end{abstract}

Keywords: heavy metals, railways, ballast, herbicides, XRF, MP-AES, Environmental Contamination, maximum permissible concentration (MPC)

\section{INTRODUCTION}

The influence of the railway transport on the environment is underestimated and underrepresented in modern science. It happens because railways are thought to be more ecologically-friendly than the automobile transport. The approximate ratio between the articles devoted to investigating the railway and road impacts on wildlife is 1 to 15 [Popp \& Boyle, 2017]. Although the railway transport has a lot of advantages compared to the automobile transport, its operation can also result in significant chemical, parametrical, biological and biocenotic pollution [Ascensão \& Capinha, 2017; Barrientos et al, 2019; Borda-de-Água et al., 2017; Lucas et al., 2017; Plakhotnik, et al., 2005; Wiłkomirski et al., 2011; Zelenko et al., 2014]. Thus, it is important to pay more scientific attention to the ecological problems of railways, which are still understudied.

In the last 20 years, the railway transport has been understood to be a source of the environmental contamination with heavy metals (HMs). [Bobryk, 2015; Bukowiecki et al., 2007; Burkhardt et al., 2008; Chen et al., 2014; Dzierżanowski \& Gawroński, 2012; Gil \& Im, 
2015; Liu et al, 2009; Ma et al., 2009; Malawska \& Wiołkomirski, 2000, 2001; Mazur et al., 2013; Meng et al., 2018; Mętrak et al., 2015; Staszewski et al., 2015; Šeda et al., 2017; Stojic et al., 2017; Wierzbicka et al., 2015; Wiłkomirski et al., 2011, 2012, 2013; Zhang et al., 2012, 2013].

The railway transport includes a lot of the HM sources, which are presented in Figure 1.

The analysis of recent publications showed that most scientists study the soil and plant contamination with HMs caused by railways, rather than the sources of HMs. However, when analyzing the HM content in soils or plants, it is difficult to identify the origin and sources of pollutants.

The aim of the research was to broaden the knowledge about the railway transport as a source of HMs. Railway ballast stones and herbicides were chosen as the objects of the research, since these sources of contamination in railway areas are hardly studied. Railway ballast is a primary and secondary source of contaminants. However, unlike soils, ballast stones can be cleaned from the metal dust much more effectively. That allows assessing the level of pollution caused by railways and the natural content of HMs in crushed stones. Railway ballast should be free from any vegetation. That is why, herbicides are frequently used for the track vegetation control, which is an important part of the railway service process and carried out every spring and summer.

The main tasks of the article include:

1) Identifying which hms and at which concentrations are contained in the railway ballast;

2) Detecting hms in the railway ballast after and before cleaning; analyzing if the herbicides contain hms;

3) Determining the origin of hms in the herbicides, based on the detected hms and their concentrations;

4) Assessing and classify the railway ballast and herbicides as a source of hms on railways;

5) Discussing other possible sources of hms on railways.

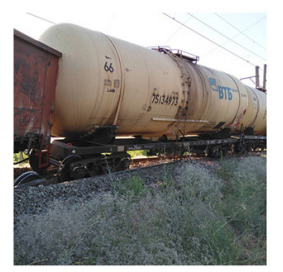

FREIGHT LOSS spillage, leakage, dusting and evaporation

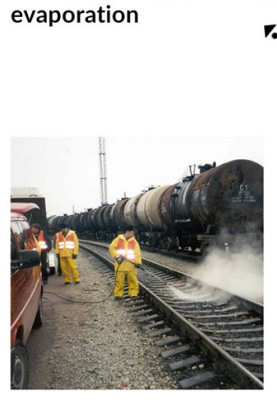

HERBICIDE USE

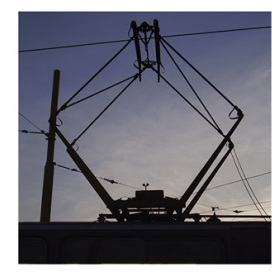

FRICTION IN THE "WHEELS-BRAKE BLOCKS", "WHEELS- BEARINGS", "WHEELS-RAILS", "PANTOGRAPH-CONTACT WIRE" SYSTEMS, ABRASION OF METAL PARTS

wheels - Fe, Mn, Ni, V brakes - Fe, Cu, Mn, Cr, Pb rails $-\mathrm{Fe}, \mathrm{Mn}, \mathrm{Cr} \quad$ galvanization $-\mathrm{Zn}, \mathrm{Cd}$



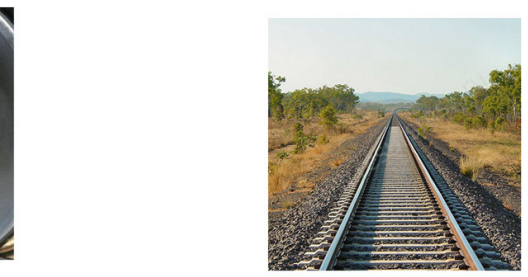

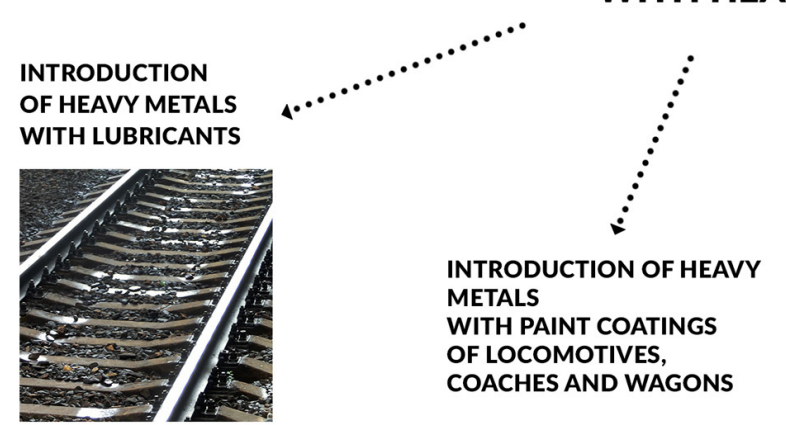

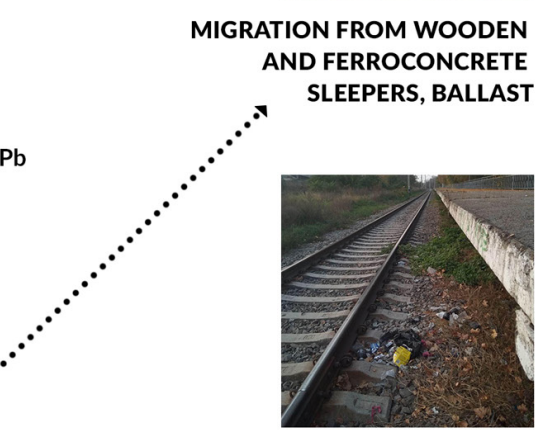

\section{DOMESTIC AND USTRIAL WASTES AS A SOURCE OF SOIL CONTAMINATION WITH HEAVY METALS INDUSTRIA}

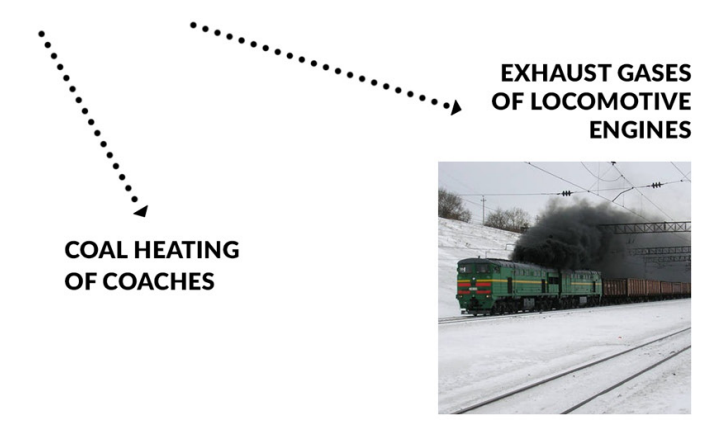

Fig. 1. The sources of heavy metals on railways 


\section{MATERIALS AND METHODS}

\section{Railway ballast}

Most railways in the world are ballasted. The ballasted track contains rails, sleepers, fasteners and ballast layer. Figure 2 shows the typical structure of the ballasted track. The thickness of ballast layer is $30-50 \mathrm{~cm}$. Up to $2000 \mathrm{~m}^{3}$ of ballast is laid per km of railway. Ballast is replaced or recovered in 15-30 years. The railway ballast performs the following functions:

- ensuring the stability of the assembled rails and sleepers under the influence of vertical, transverse, horizontal and longitudinal horizontal forces;

- perceiving concentrated pressures from sleepers, distributing them on the largest possible platforms and to transfer these pressures to the main platform of earthworks most evenly;

- converting elastically impulse dynamic and shock-dynamic forces acting from rails on sleepers and from sleepers on ballast;
- draining atmospheric water, preventing its accumulation on the upper structure of the track and divert it from the track.

The railway ballast stones were sampled on January 24th, 2020. The sampling location was the "Kamianske-Pasazhyrske" railway station $\left(48^{\circ} 29^{\prime} 50.4^{\prime} \mathrm{N} 34^{\circ} 36^{\prime} 15.1^{\prime \prime} \mathrm{E}\right)$. It is a passenger station, where most long-distance trains stop, including high-speed "Intercity+" trains, as well as all suburban electric trains. The station has three tracks and two platforms. The stones were sampled from the three tracks. The first and third tracks are the main ones. The second one is additional, which is mainly used for suburban trains. Figure 3 presents the sampling location.

This railway is characterized by the high traffic intensity. According to the traffic schedule, on average, 40 suburban trains and 35 long-distance trains pass through the above-mentioned station. In summer, the number of long distance trains increases (up to 45). The freight trains going through the station mainly carry the iron and manganese ores, ferrous metals and their scrap,

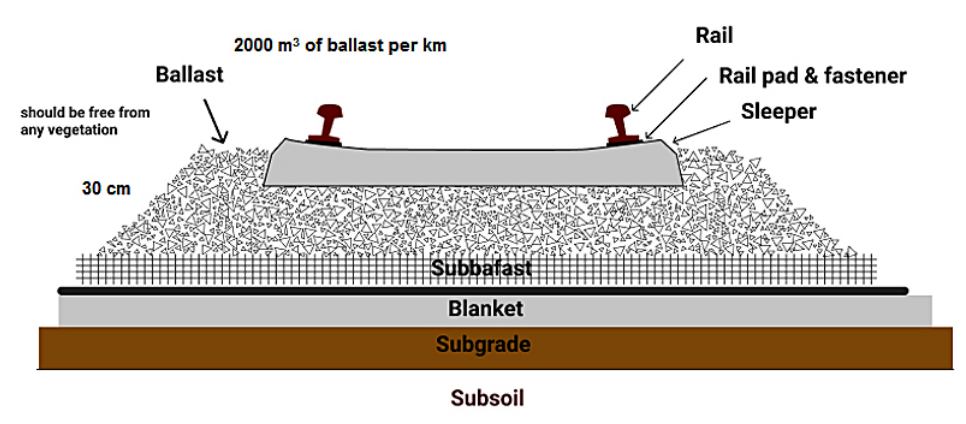

Fig. 2. The typical structure of the ballasted track

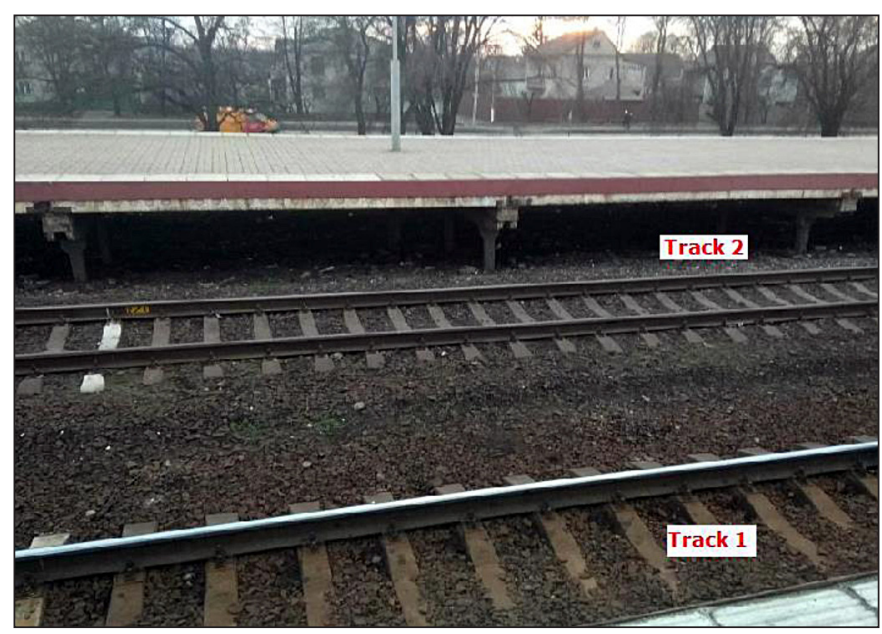

Fig. 3. The sampling site 
coal, coke, cement, chemical and mineral fertilizers, oil and oil-products and others. The railway station is electrified and equipped with ferroconcrete sleepers. The fresh ballast layer was laid in 2008. The ballast material is granite.

\section{Herbicides for controlling railway vegetation}

Safe and reliable railway operations in general, the service life of the track structure and the condition of the earthworks depend directly upon the condition and proper operation of the ballast layer. Any vegetation in the area of the ballast prism is a risk factor of reducing the level of traffic safety due to retaining water and reducing the wheel and rail adhesion [SBB, 2001; Thommesen, 2014]

The herbicide use is an economical method of vegetation control, but is effective only in short term and is environmentally harmful. It should be noted that the consequences of herbicide use on railways are seldom investigated. There are several articles devoted to this problem [Ramwell, et al., 2004; Schweinsberg et al., 1999; Skark et al., 2004]. Although this method has a lot of shortcomings from an ecological point of view, it has several advantages and is still widely used on railways all over the world. Ecological audits showed that using the thermal methods aimed at decreasing of vegetation cover requires from 5 to 14 times more energy in comparison with the application of the chemical methods [SBB, 2001].

Herbicides № 4 and 5 are effective against a broad range of resistant weeds: false wheat (Agropyron repens), field bindweed (Convolvulus arvensis), thistle (Carduus L.) and field horsetail (Equisetum arvense), all of which are widely occur in Ukraine. All these types of weeds are problematic during railway service. Rather than glyphosate, herbicides № 4 and 5 can destroy such persistent weeds due to other active agents. Field horsetail is known not to be sensitive to glyphosate. The labels of all the herbicides state that it is a poison and precautionary measures should be taken during their use. Only the active ingredients are provided on the label.

In order to carry out the investigation, three glyphosate-based herbicides and two combination system herbicides of burn-down with other active agents (№ 4 and 5) were chosen. The herbicides were diluted 1:10 ( $1 \mathrm{ml}$ of each herbicide, $8.5 \mathrm{ml}$ of distilled water and $0.5 \mathrm{ml}$ of nitric acid). Table 1 presents the characteristics of the herbicides.

\section{X-ray fluorescence analysis for heavy metal detection}

The HM content in the railway ballast stones was detected by means of the X-ray fluorescence analysis. It is a qualitative and quantitative analysis for the determination of many elements in solids, highly concentrated liquids, powders, and alloys.

$\mathrm{X}$-ray fluorescence spectroscopy is based on the wavelength-dispersive principle, which states that individual atoms emit a relative abundance of X-ray photons of energy or wavelength feature that can be estimated [Weltje \& Tjallingii, 2008]. The X-ray fluorescence technique has a lot of advantages. The first one is its ability to conduct the analyses the bulk chemical content of major elements. The main-filter elements are $\mathrm{Mn}, \mathrm{Fe}, \mathrm{Co}, \mathrm{Ni}, \mathrm{Cu}, \mathrm{Zn}, \mathrm{As}, \mathrm{Se}, \mathrm{Rb}, \mathrm{Sr}, \mathrm{Zr}$, $\mathrm{Nb}, \mathrm{Mo}, \mathrm{Au}, \mathrm{Pb}$ and $\mathrm{Bi}$. The high-filter elements are $\mathrm{Pd}, \mathrm{Ag}, \mathrm{Cd}, \mathrm{Sn}, \mathrm{Sb}$ and $\mathrm{Ba}$. The X-ray emission used in X-ray fluorescence spectrometry is simple, systematic, relatively independent of the

Table 1. The characteristics of the investigated herbicides

\begin{tabular}{|c|c|c|c|c|c|c|}
\hline \multirow{2}{*}{ № } & \multirow{2}{*}{ Name } & \multicolumn{2}{|c|}{$\begin{array}{c}\text { Ingredients } \\
\text { Concentration of the active agents }\end{array}$} & \multirow{2}{*}{ Solution color } & \multirow{2}{*}{$\begin{array}{l}\text { Class of } \\
\text { hazard }\end{array}$} & \multirow{2}{*}{$\begin{array}{l}\text { Producer } \\
\text { country }\end{array}$} \\
\hline & & glyphosate & other active agents & & & \\
\hline 1 & Round up & $360 \mathrm{~g} / \mathrm{L}$ & - & Green & $\begin{array}{l}\text { The label } \\
\text { doesn't } \\
\text { state }\end{array}$ & Belgium \\
\hline 2 & Napalm Forte & $550 \mathrm{~g} / \mathrm{L}$ (potassium salt) & - & Brown & III & China \\
\hline 3 & Tornado Forte & $500 \mathrm{~g} / \mathrm{L}$ & - & Dark orange & III & Switzerland \\
\hline 4 & Federal & $\begin{array}{l}480 \mathrm{~g} / \mathrm{L} \text { of glyphosate } \\
\text { isopropylamine salt }\end{array}$ & $60 \mathrm{~g} / \mathrm{L}$ dicamba & Yellow & III & Ukraine \\
\hline 5 & $\begin{array}{l}\text { Anti field } \\
\text { bindweed }\end{array}$ & $480 \mathrm{~g} / \mathrm{L}$ & $\begin{array}{c}905 \mathrm{~g} / \mathrm{L} \text { of 2-ethylhexyl ester; } \\
600 \mathrm{~g} / \mathrm{L} \text { of } 2,4 \\
\text { dichlorophenoxyacetic acid }\end{array}$ & Turbid yellow & $\begin{array}{l}\text { The label } \\
\text { doesn't } \\
\text { state }\end{array}$ & Belarus \\
\hline
\end{tabular}


chemical state, and with uniform excitation and absorption dependent on an atomic number. In addition, the interference in the line of X-ray radiation can be corrected, thereby enabling high accuracy and precision to be easily attained. Another advantage of XRF is the sample preparation, which is simple, time saving and non-destructive [Oyedotun, 2018].

The hXRF measuring device functional principle is as follows:

- tube voltage: $50 \mathrm{kV}$

- X-ray tube: Ag

- detector: „GOLDD“ (SiliziumDrift-Detector)

- measuring zone: $8 \mathrm{~mm}$

- helium-flushing is possible

Figure 4 shows the used hXRF measuring device and the obtained results.

The investigation was carried out at the laboratory of water chemistry analysis, TU Bergakademie Freiberg, Institut für Bergbau und Spezialtiefbau.

\section{MP-AES for heavy metal detection}

The HM content in the herbicides was detected by means of Microwave Plasma-Atomic Emission Spectroscopy (Model: 4200 MP-AES, G8003A MP-AES, Serial No. MY1447000). In recent years, MP-AES has slowly been emerging as one of the most powerful and popular analytical tools for the analysis of various materials and elements. MP-AES uses the nitrogen plasma instead of the argon plasma, which is used in ICP-OE. The nitrogen plasma is sustained by a lower pressure microwave source that operates at atmospheric pressure. Nitrogen is non-flammable and cost-efficient, and can be easily sourced from the atmospheric air using a compressor. Moreover, the nitrogen plasma temperature is lower $(5000 \mathrm{~K})$ compared to the argon plasma (8000-10,000 K) [Donati et al., 2013; Vudagandla et al., 2017]. As a result of this temperature difference, the spectral interferences are less significant and the majority of elements remain in the atomic state, thereby resulting in simpler atomic emission spectral lines than those obtained with the argon plasma [Balaram et al., 2014; Vudagandla et al., 2017].

Short characteristics of MP-AES 4200:

- atomizer: microwave excited plasma

- plasma gas: nitrogen

- axial magnetic and radial electrical fields generated by a magnetron

- sample aerosol is introduced into the nitrogen plasma.

Table 2 presents the wavelength for measuring each metal, limits of detection and quantitation $(\mathrm{mg} / \mathrm{L})$. The measurement was carried out at

b)

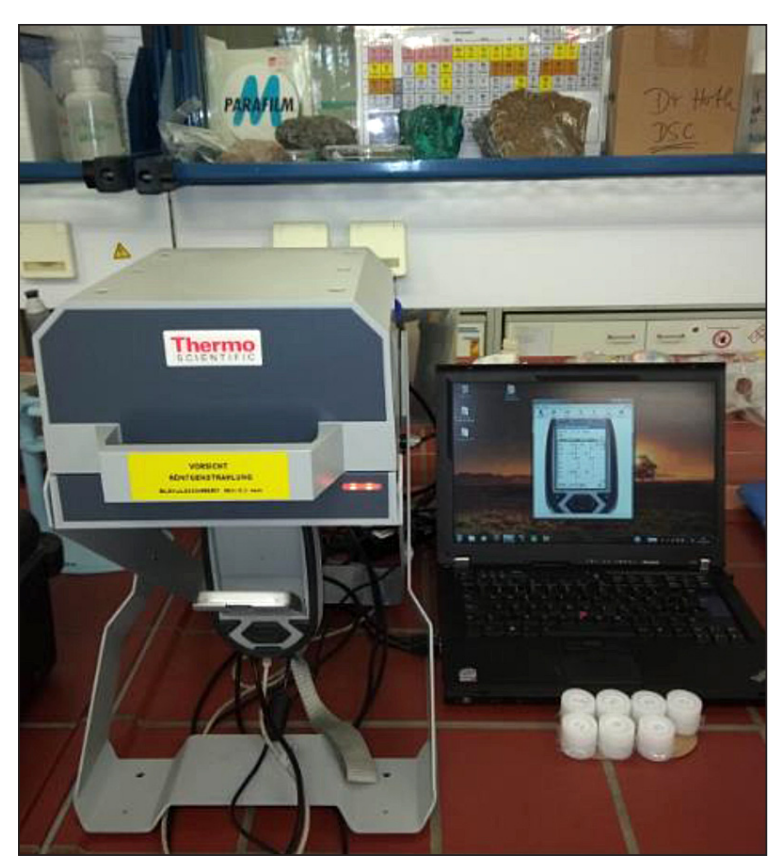

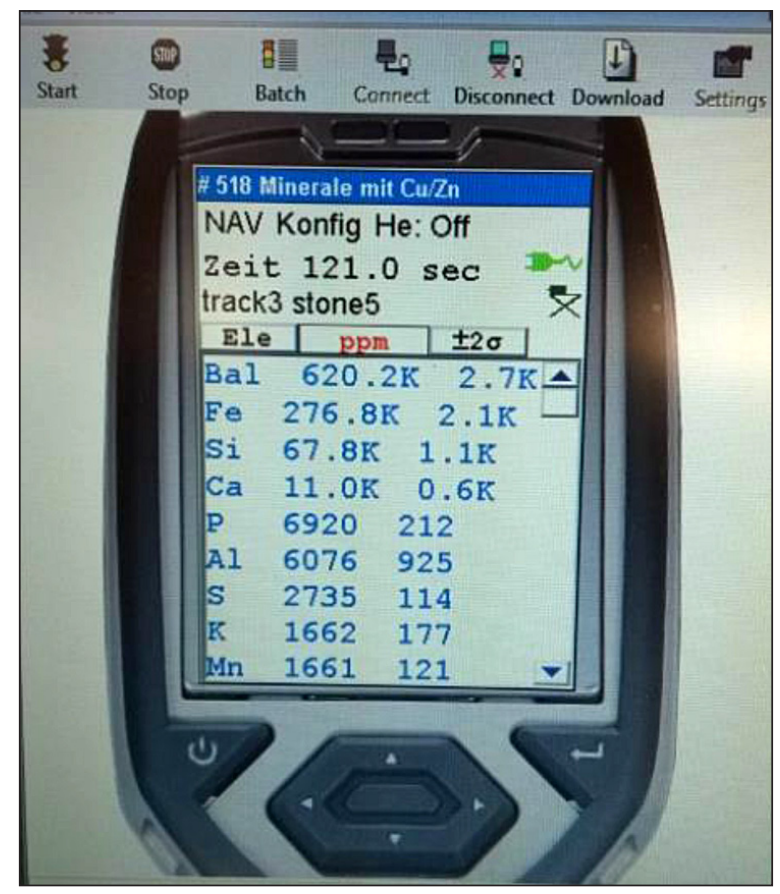

Fig. 4. The appearance of the used hXRF measuring device and the obtained result 
Table 2. Some measuring characteristics for HM detection

\begin{tabular}{|c|c|c|c|}
\hline Element & Wave-length, $\mathrm{nm}$ & LOD (Limit of detection) & LOQ (Limit of quantitation) \\
\hline $\mathrm{Cd}$ & $228.802 \mathrm{~nm}$ & 0.0014 & 0.0129 \\
\hline $\mathrm{Co}$ & $340.512 \mathrm{~nm}$ & 0.0374 & 0.0277 \\
\hline $\mathrm{Cu}$ & $324.754 \mathrm{~nm}$ & 0.0098 & 0.0155 \\
\hline $\mathrm{Fe}$ & $371.993 \mathrm{~nm}$ & 0.0272 & 0.0387 \\
\hline $\mathrm{Mn}$ & $403.076 \mathrm{~nm}$ & 0.0021 & 0.0049 \\
\hline $\mathrm{Ni}$ & $352.454 \mathrm{~nm}$ & 0.0233 & 0.0354 \\
\hline $\mathrm{Pb}$ & $405.781 \mathrm{~nm}$ & 0.0386 & 0.0495 \\
\hline $\mathrm{Zn}$ & $213.857 \mathrm{~nm}$ & 0.0040 & 0.0180 \\
\hline
\end{tabular}

the laboratory of water chemistry analysis, TU Bergakademie Freiberg, Institut für Bergbau und Spezialtiefbau.

\section{RESULTS AND DISCUSSION}

\section{Heavy metal content in railway stones}

More than 30 elements were analyzed. Table 3 presents the content of HMs in the railway ballast. After analyzing the samples, the Pearson correlation coefficient was calculated for 11 elements. Table 4 presents the calculated coefficient.

The concentration of $\mathrm{Cd}, \mathrm{Co}, \mathrm{Mo}, \mathrm{Pd}, \mathrm{Sn}$ and $\mathrm{W}$ in each sample was below the limit of detection, which does not allow excluding the possibility that the railway ballast might be an insignificant source of these metals. As a rule, only two of the above metals, namely, $\mathrm{Cd}$ and $\mathrm{Co}$ are related to railway operations. It has been proven that the railway soil contamination with cobalt was negligible [Malawska \& Wiołkomirski, 2001; Mazur et al. 2013; Mętrak et al. 2015; Wiłkomirski et al., 2011]. The sources of the cobalt pollution on railways are the oils for processing wooden sleepers, the coal and fuel combustion and herbicides [Defarge et al., 2018; Mazur et al., 2013; Zelenko \& Samarska, 2014].

As for cadmium, it is a highly toxic metal. The possible Cd sources are the exhaust gases of locomotives, which are absent for the investigated station. While this metal was identified as one of the priority pollutants on the Chinese railways [Chen et al., 2014; Liu et al., 2009; Ma et al., 2009; Zhang et al., 2012, 2013], most studies indicated that the soil pollution with $\mathrm{Cd}$ due to the railway operations was minimal [Malawska \& Wiołkomirski, 2001; Mazur et al., 2013; Mętrak et al., 2015; Stojic et al., 2017; Wiłkomirski et al., 2011].
Arsenic (As). The arsenic content varied from $9.52 \pm 4.25$ to $34.13 \pm 7.25 \mathrm{ppm}$. In eight samples, the As concentration was below the limit of detection. According to the obtained results, which were minimal for this metalloid, the railway ballast cannot be considered as a serious source of As. Wiłkomirski et al. [2013] proved that the soil contamination with arsenic in the area of the track was low enough. The possible source of the As pollution on railways is herbicides, which can contain this metalloid [Defarge et al., 2018]. Arsenic has been used as a pesticide for decades [ $\mathrm{Li}$ et al., 2016; Murphy \& Aucott, 1998].

Lead (Pb). The lead concentration was mostly below the limit of detection (18 samples), which proves that the railway ballast stones are not a source of this heavy and toxic metal. The natural content of lead in some soils can be higher than that in the investigated stones. The highest $\mathrm{Pb}$ content was $33.42 \pm 5.59 \mathrm{ppm}$, the lowest one $-13.08 \pm 6.08 \mathrm{ppm}$. As a comparison, the background concentration of lead for Dnipropetrovsk oblast is $10 \mathrm{mg} / \mathrm{kg}$.

The railway impact on the soil contamination with $\mathrm{Pb}$ is ambiguous due to the fact that the research was carried out on both electrified and non-electrified railways. On the non-electrified railways, the exhaust gases of locomotives are intensive HM sources. According to the Chinese researchers, $\mathrm{Pb}$ was one of the three major contaminants in the railway infrastructure, along with such metals as $\mathrm{Cd}$ and $\mathrm{Zn}$. The research was carried out in the high-mountain Tibet railway, which is not electrified [Zhang et al., 2012, 2013].

It should be noted that lead was found only in the samples from track 2, which is additional and used for suburban trains. This can be explained by the fact that trains can stand at track 2 for 30 minutes or even more. In this time, different lubricants may drip on the track. Moreover, the lead content is not correlated with that of other metals. 
Table 3. The content of heavy metals in the railway ballast stones, ppm (part per million)

\begin{tabular}{|c|c|c|c|c|c|c|c|c|}
\hline Sample & As & $\mathrm{Cr}$ & $\mathrm{Cu}$ & $\mathrm{Fe}$ & $\mathrm{Mn}$ & $\mathrm{Ni}$ & $\mathrm{Pb}$ & $\mathrm{Zn}$ \\
\hline Track 1, stone 1 & $\begin{array}{l}25.83 \\
\pm 6.91\end{array}$ & $\begin{array}{l}372.67 \\
\pm 49.68\end{array}$ & $\begin{array}{l}240.32 \\
\pm 28.97\end{array}$ & $\begin{array}{c}259782.14 \\
\pm 1885.68\end{array}$ & $\begin{array}{c}1987.2 \\
\pm 123.73\end{array}$ & $\begin{array}{l}351.23 \\
\pm 46.72\end{array}$ & $<$ LOD & $\begin{array}{r}48.45 \\
\pm 12.96\end{array}$ \\
\hline Track 1 , stone 2 & $\begin{array}{l}15.39 \\
\pm 4.53 \\
\end{array}$ & $\begin{array}{l}306.86 \\
\pm 40.36\end{array}$ & $\begin{array}{l}184.97 \\
\pm 21.05\end{array}$ & $\begin{array}{c}166049.73 \\
\pm 1078.59\end{array}$ & $\begin{array}{c}1292.23 \\
\pm 96.74\end{array}$ & $\begin{array}{l}269.47 \\
\pm 34.09\end{array}$ & $<$ LOD & $\begin{array}{c}36.02 \\
\pm 9.5\end{array}$ \\
\hline Track 1 , stone 3 & $\begin{array}{r}18.03 \\
\pm 5.26 \\
\end{array}$ & $\begin{array}{r}332.88 \\
\pm 43.25 \\
\end{array}$ & $\begin{array}{r}117.42 \\
\pm 19.33 \\
\end{array}$ & $\begin{array}{c}158418.45 \\
\pm 1054.45\end{array}$ & $\begin{array}{c}1221.03 \\
\pm 97.55\end{array}$ & $\begin{array}{l}280.52 \\
\pm 35.13 \\
\end{array}$ & $<$ LOD & $\begin{array}{r}48.60 \\
\pm 10.23 \\
\end{array}$ \\
\hline Track1, stone 4 & $<$ LOD & $\begin{array}{l}65.86 \\
\pm 21.2 \\
\end{array}$ & $<$ LOD & $\begin{array}{c}31215.31 \\
\pm 298.07\end{array}$ & $\begin{array}{l}208.05 \\
\pm 66.66 \\
\end{array}$ & $<$ LOD & $<$ LOD & $\begin{array}{l}24.62 \\
\pm 6.98 \\
\end{array}$ \\
\hline Track 1, stone 5 & $\begin{array}{l}16.14 \\
\pm 5.01\end{array}$ & $\begin{array}{l}374.47 \\
\pm 45.13\end{array}$ & $\begin{array}{l}215.44 \\
\pm 23.95\end{array}$ & $\begin{array}{c}169542.69 \\
\pm 1151.72\end{array}$ & $\begin{array}{c}1427.27 \\
\pm 103.8\end{array}$ & $\begin{array}{l}221.56 \\
\pm 37.36\end{array}$ & $<$ LOD & $\begin{array}{c}39.64 \\
\pm 10.56\end{array}$ \\
\hline Track 1 , stone 6 & $\begin{array}{r}19.81 \\
\pm 6.54 \\
\end{array}$ & $\begin{array}{l}412.25 \\
\pm 50.33 \\
\end{array}$ & $\begin{array}{r}143.93 \\
\pm 24.89 \\
\end{array}$ & $\begin{array}{c}244512.73 \\
\pm 1766.75 \\
\end{array}$ & $\begin{array}{r}1846.05 \\
\pm 120.39 \\
\end{array}$ & $\begin{array}{l}407.16 \\
\pm 46.58 \\
\end{array}$ & $<$ LOD & $\begin{array}{c}61.57 \\
\pm 13.22 \\
\end{array}$ \\
\hline Track 1 , stone 7 & $<$ LOD & $\begin{array}{c}54.41 \\
\pm 25.08\end{array}$ & $<$ LOD & $\begin{array}{c}46946.84 \\
\pm 377.53\end{array}$ & $\begin{array}{c}469.1 \\
\pm 73.01\end{array}$ & $\begin{array}{c}62.94 \\
\pm 25.58\end{array}$ & $<$ LOD & $\begin{array}{l}36.90 \\
\pm 7.67\end{array}$ \\
\hline Track 1 , stone 8 & $<$ LOD & $<$ LOD & $\begin{array}{c}36.45 \\
\pm 13.14 \\
\end{array}$ & $\begin{array}{c}48766.76 \\
\pm 396.4 \\
\end{array}$ & $\begin{array}{l}496.27 \\
\pm 75.09 \\
\end{array}$ & $\begin{array}{c}42.97 \\
\pm 26.04 \\
\end{array}$ & $<$ LOD & $\begin{array}{l}42.64 \\
\pm 8.14 \\
\end{array}$ \\
\hline Track 1 , stone 9 & $\begin{array}{r}14.36 \\
\pm 4.33 \\
\end{array}$ & $\begin{array}{c}322.7 \\
\pm 43.96 \\
\end{array}$ & $\begin{array}{r}152.48 \\
\pm 19.15 \\
\end{array}$ & $\begin{array}{c}141038.06 \\
\pm 921 \\
\end{array}$ & $\begin{array}{l}1177.11 \\
\pm 93.19 \\
\end{array}$ & $\begin{array}{l}257.42 \\
\pm 31.97 \\
\end{array}$ & $<$ LOD & $\begin{array}{l}57.27 \\
\pm 9.96 \\
\end{array}$ \\
\hline Track 2, stone 1 & $\begin{array}{l}22.75 \\
\pm 5.71 \\
\end{array}$ & $\begin{array}{l}386.61 \\
\pm 45.41 \\
\end{array}$ & $\begin{array}{l}246.86 \\
\pm 26.46 \\
\end{array}$ & $\begin{array}{c}226963.14 \\
\pm 1570.28 \\
\end{array}$ & $\begin{array}{l}1650.57 \\
\pm 111.67 \\
\end{array}$ & $\begin{array}{l}347.57 \\
\pm 41.14 \\
\end{array}$ & $<$ LOD & $\begin{array}{c}55.33 \\
\pm 12.03 \\
\end{array}$ \\
\hline Track 2, stone 2 & $<$ LOD & $\begin{array}{l}151.74 \\
\pm 27.58 \\
\end{array}$ & $\begin{array}{l}293.43 \\
\pm 19.91 \\
\end{array}$ & $\begin{array}{c}50225.88 \\
\pm 409.47 \\
\end{array}$ & $\begin{array}{l}405.23 \\
\pm 73.09 \\
\end{array}$ & $\begin{array}{c}86.98 \\
\pm 26.67 \\
\end{array}$ & $\begin{array}{l}28.38 \\
\pm 5.79 \\
\end{array}$ & $\begin{array}{l}50.38 \\
\pm 8.56 \\
\end{array}$ \\
\hline Track 2, stone 3 & $\begin{array}{c}21.02 \\
\pm 5\end{array}$ & $\begin{array}{l}304.29 \\
\pm 41.45\end{array}$ & $\begin{array}{l}884.13 \\
\pm 34.35\end{array}$ & $\begin{array}{c}140047.66 \\
\pm 883.57\end{array}$ & $\begin{array}{c}1007.28 \\
\pm 86.78\end{array}$ & $\begin{array}{l}215.73 \\
\pm 30.58\end{array}$ & $<$ LOD & $\begin{array}{c}120.28 \\
\pm 12.6\end{array}$ \\
\hline Track 2, stone 4 & $<$ LOD & $\begin{array}{c}107.1 \\
\pm 20.63 \\
\end{array}$ & $\begin{array}{l}109.83 \\
\pm 14.65 \\
\end{array}$ & $\begin{array}{c}34675.66 \\
\pm 319.4\end{array}$ & $\begin{array}{l}253.78 \\
\pm 68.79 \\
\end{array}$ & $<$ LOD & $\begin{array}{l}33.42 \\
\pm 5.59 \\
\end{array}$ & $\begin{array}{c}19.64 \\
\pm 6.9 \\
\end{array}$ \\
\hline Track 2, stone 5 & $<$ LOD & $\begin{array}{l}133.42 \\
\pm 25.53 \\
\end{array}$ & $\begin{array}{l}269.14 \\
\pm 20.23 \\
\end{array}$ & $\begin{array}{c}46996.76 \\
\pm 406.07 \\
\end{array}$ & $\begin{array}{r}453.06 \\
\pm 77.45 \\
\end{array}$ & $\begin{array}{l}76.53 \\
\pm 28.5 \\
\end{array}$ & $\begin{array}{l}14.07 \\
\pm 5.34 \\
\end{array}$ & $\begin{array}{l}48.09 \\
\pm 9.03 \\
\end{array}$ \\
\hline Track 2, stone 6 & $\begin{array}{r}19.78 \\
\pm 7.19 \\
\end{array}$ & $\begin{array}{l}467.88 \\
\pm 61.71 \\
\end{array}$ & $\begin{array}{l}807.87 \\
\pm 42.49 \\
\end{array}$ & $\begin{array}{l}230104.8 \\
\pm 1648.94 \\
\end{array}$ & $\begin{array}{l}2435.93 \\
\pm 128.55 \\
\end{array}$ & $\begin{array}{l}306.01 \\
\pm 44.91 \\
\end{array}$ & $<$ LOD & $\begin{array}{r}188.59 \\
\pm 18.76 \\
\end{array}$ \\
\hline Track 2, stone 7 & $<$ LOD & $\begin{array}{r}194.89 \\
\pm 31.82 \\
\end{array}$ & $\begin{array}{l}252.64 \\
\pm 19.55 \\
\end{array}$ & $\begin{array}{l}82782.3 \\
\pm 566.94 \\
\end{array}$ & $\begin{array}{l}616.53 \\
\pm 76.71 \\
\end{array}$ & $\begin{array}{r}82.33 \\
\pm 26.26 \\
\end{array}$ & $\begin{array}{l}15.69 \\
\pm 5.64 \\
\end{array}$ & $\begin{array}{l}48.98 \\
\pm 8.64 \\
\end{array}$ \\
\hline Track 2, stone 8 & $<$ LOD & $\begin{array}{c}97.66 \\
\pm 29.92\end{array}$ & $\begin{array}{r}130.78 \\
\pm 16.76\end{array}$ & $\begin{array}{c}50328.88 \\
\pm 419.82\end{array}$ & $\begin{array}{l}469.26 \\
\pm 77.57\end{array}$ & $\begin{array}{c}64.84 \\
\pm 27.66 \\
\end{array}$ & $\begin{array}{l}13.23 \\
\pm 5.73\end{array}$ & $\begin{array}{l}59.14 \\
\pm 9.09\end{array}$ \\
\hline Track 2, stone 9 & $\begin{array}{c}10.06 \pm \\
4.87\end{array}$ & $\begin{array}{l}249.62 \\
\pm 39.58 \\
\end{array}$ & $\begin{array}{l}381.45 \\
\pm 24.01 \\
\end{array}$ & $\begin{array}{c}112064.48 \\
\pm 746.89\end{array}$ & $\begin{array}{l}1182.38 \\
\pm 91.51\end{array}$ & $\begin{array}{l}185.26 \\
\pm 30.57 \\
\end{array}$ & $\begin{array}{l}13.08 \\
\pm 6.08 \\
\end{array}$ & $\begin{array}{r}143.28 \\
\pm 12.71 \\
\end{array}$ \\
\hline Track 3 , stone 1 & $\begin{array}{l}24.25 \\
\pm 6.08 \\
\end{array}$ & $\begin{array}{l}385.96 \\
\pm 46.33 \\
\end{array}$ & $\begin{array}{l}190.72 \\
\pm 24.51 \\
\end{array}$ & $\begin{array}{c}213831.22 \\
\pm 1492.63 \\
\end{array}$ & $\begin{array}{r}1426.44 \\
\pm 108.08 \\
\end{array}$ & $\begin{array}{l}348.70 \\
\pm 41.27 \\
\end{array}$ & $<$ LOD & $\begin{array}{r}72.62 \\
\pm 12.73 \\
\end{array}$ \\
\hline Track 3 , stone 2 & $\begin{array}{l}20.67 \\
\pm 6.12 \\
\end{array}$ & $\begin{array}{l}374.74 \\
\pm 52.88 \\
\end{array}$ & $\begin{array}{l}235.39 \\
\pm 25.84 \\
\end{array}$ & $\begin{array}{c}190313.83 \\
\pm 1323.30 \\
\end{array}$ & $\begin{array}{l}1505.58 \\
\pm 108.48 \\
\end{array}$ & $\begin{array}{l}299.05 \\
\pm 40.91 \\
\end{array}$ & $<$ LOD & $\begin{array}{r}115.99 \\
\pm 14.43 \\
\end{array}$ \\
\hline Track 3 , stone 3 & $\begin{array}{r}10.80 \\
\pm 3.91 \\
\end{array}$ & $\begin{array}{l}241.65 \\
\pm 35.17 \\
\end{array}$ & $\begin{array}{c}90.10 \\
\pm 15.69 \\
\end{array}$ & $\begin{array}{c}107672.30 \\
\pm 708.41 \\
\end{array}$ & $\begin{array}{l}778.51 \\
\pm 81.50 \\
\end{array}$ & $\begin{array}{l}171.29 \\
\pm 28.57 \\
\end{array}$ & $<$ LOD & $<$ LOD \\
\hline Track 3, stone 4 & $\begin{array}{l}29.02 \\
\pm 7.08 \\
\end{array}$ & $\begin{array}{l}429.78 \\
\pm 52.40 \\
\end{array}$ & $\begin{array}{l}466.74 \\
\pm 35.26 \\
\end{array}$ & $\begin{array}{c}251849.23 \\
\pm 1844.57 \\
\end{array}$ & $\begin{array}{l}1597.74 \\
\pm 117.14 \\
\end{array}$ & $\begin{array}{l}405.74 \\
\pm 46.33 \\
\end{array}$ & $<$ LOD & $\begin{array}{r}109.59 \\
\pm 16.12 \\
\end{array}$ \\
\hline Track 3 , stone 5 & $\begin{array}{l}34.13 \\
\pm 7.25 \\
\end{array}$ & $\begin{array}{l}429.91 \\
\pm 49.36 \\
\end{array}$ & $\begin{array}{l}770.36 \\
\pm 44.64 \\
\end{array}$ & $\begin{array}{c}276754.34 \\
\pm 2068.07 \\
\end{array}$ & $\begin{array}{r}1661.37 \\
\pm 120.75 \\
\end{array}$ & $\begin{array}{l}370.91 \\
\pm 48.68 \\
\end{array}$ & $<$ LOD & $\begin{array}{r}124.92 \\
\pm 17.54 \\
\end{array}$ \\
\hline Track 3, stone 6 & $\begin{array}{c}9.52 \\
\pm 4.25\end{array}$ & $\begin{array}{r}195.12 \\
\pm 37.54\end{array}$ & $\begin{array}{r}127.71 \\
\pm 16.97\end{array}$ & $\begin{array}{c}108260.59 \\
\pm 714.86\end{array}$ & $\begin{array}{r}772.61 \\
\pm 81.83 \\
\end{array}$ & $\begin{array}{r}158.07 \\
\pm 28.53\end{array}$ & $<$ LOD & $<$ LOD \\
\hline
\end{tabular}

To sum up, according to the obtained results, lead is not a typical metal for both the ballast stones and passenger stations, which are electrified. For reference, the emission of lead due to the friction processes on the Swiss Federal Railways was $0.5 \mathrm{~g} / \mathrm{km}$, while that of iron, copper, zinc and manganese was 302000 , 6480,2750 and $2170 \mathrm{~g} / \mathrm{km}$, respectively [Burkhardt et al., 2008].

Iron $(\mathbf{F e})$. All the samples contained a significant amount of iron, which is one of the most widespread metals in the Earth's crust, second to aluminum. The highest content of iron was detected in stone 5 from track 3 $276754.34 \pm 2068.07 \mathrm{ppm}$, the lowest one - in stone 4 , track $1-31215.31 \pm 298.07 \mathrm{ppm}$. Such variability of the data can be explained by that the samples were unevenly covered with the metal dust due to their locations. The sampling was carried out along $100 \mathrm{~m}$. The mean value for $\mathrm{Fe}$ was $141214.32 \pm 81499.35 \mathrm{ppm}$. Therefore, the railway ballast is a significant source 
of iron. In addition, the railway operations result in the environmental contamination with iron, which is obvious, since rails, locomotives and rolling stock are made of steel, the main component of which is iron. The Fe contamination could be seen without a laboratory analysis, because the railway ballast and soil are often covered with the iron corrosion products (see figure 5).

The high levels of the Fe content in soil were detected on the Polish railway [Dzierżanowski \& Gawroński, 2012; Wiłkomirski et al., 2011]. Moreover, the significant Fe content was found in the dust settled at the northern railway station of the Shijiazhuang city and on the Sidney railway [Mohsen et al., 2018; Wan et al., 2016].

The content of iron in the samples was strongly correlated with that of nickel ( $\mathrm{r}=$ $0.972)$, chromium $(r=0.954)$ and manganese $(\mathrm{r}=0.943)$. In addition, the content of nickel was strongly correlated with that of chromium $(\mathrm{r}=0.935)$ and manganese $(\mathrm{r}=0.890)$. The correlation coefficient between manganese and chromium was 0.943 . Such strong correlations testify that these 4 metals have the same origin. The source of Fe, $\mathrm{Ni}, \mathrm{Cr}$ and $\mathrm{Mn}$ is the abrasion of steel rails and wheels, which is typical for passenger stations, where trains stop or slow down. $\mathrm{Ni}, \mathrm{Cr}$ and $\mathrm{Mn}$ are alloying metals, which increase the strength and corrosion resistance of steel, reduce the risk of brittle fracture.

Manganese (Mn). All the samples also contained $\mathrm{Mn}$ in the concentration from $208.05 \pm 66.66 \mathrm{ppm}$ to $2435.93 \pm 128.55 \mathrm{ppm}$, which proves that railway ballast is a significant source of this metal. The mean content of $\mathrm{Mn}$ in the stones was $1097.52 \pm 606.59 \mathrm{ppm}$. On railways, the Mn emission sources are correlated with those of iron: the abrasion of rails, wheels, brakes and freight loss (iron and manganese ores are the most transported freight by railways in Ukraine), but manganese is introduced in smaller quantities.

The railway contribution to the soil contamination with manganese was confirmed by many studies, although Mn did not rank first among other HMs [Liu et al., 2009; Dzierżanowski \& Gawroński, 2012; Mazur et al., 2013; Wiłkomirski et al., 2013; Samarska \& Zelenko, 2018ª 2018 Staszewski et al., 2015].

Zinc (Zn). The zinc concentration was medium, this metal was not detected only in two samples. Its highest concentration was $188.59 \pm 18.76 \mathrm{ppm}$, whereas the lowest content was $19.64 \pm 6.9 \mathrm{ppm}$, which allows determining the railway ballast as a moderate source of $\mathrm{Zn}$. As for other $\mathrm{Zn}$ sources on railways, Liu et al. [2009] found the increased $\mathrm{Zn}$ content in the direct proximity to the track, the origin of which may include oils, lubricants, and paints. According to Plakhotnik et al. [2005] the Zn contamination could result from litter and transported freight. The galvanic coating abrasion also results in the zinc emission (the third place after Fe and $\mathrm{Cu}$ ) [Burkhardt et al., 2008]. Moreover, zinc may be contained in rubber, used for strengthening the slopes [Zelenko \& Samarska, 2014].

Most researchers determined this metal as one of the priority soil contaminants in the railway areas [Meng et al., 2018; Stojic et al., 2017; Wiłkomirski et al., 2011]. However, our results did not confirm the significant railway contribution to the ballast contamination with zinc.

Copper (Cu). Copper was not detected only in two samples. The other samples contained $\mathrm{Cu}$ from $36.45 \pm 13.14 \mathrm{ppm}$ to $884.13 \pm 34.35 \mathrm{ppm}$.

Table 4. Correlations between elements in the samples of the contaminated ballast from

\begin{tabular}{|c|c|c|c|c|c|c|c|c|c|c|c|}
\hline Elements & $\mathrm{Fe}$ & $\mathrm{Ni}$ & $\mathrm{Cr}$ & $\mathrm{Mn}$ & $\mathrm{Zn}$ & $\mathrm{Cu}$ & $\mathrm{Ti}$ & $\mathrm{Pb}$ & $\mathrm{Rb}$ & $\mathrm{Si}$ & $\mathrm{Al}$ \\
\hline $\mathrm{Fe}$ & 1 & & & & & & & & & & \\
\hline $\mathrm{Ni}$ & $\mathbf{0 . 9 7 2 *}$ & 1 & & & & & & & & & \\
\hline $\mathrm{Cr}$ & $\mathbf{0 . 9 5 4 ^ { * }}$ & $\mathbf{0 . 9 3 5 ^ { * }}$ & 1 & & & & & & & & \\
\hline $\mathrm{Mn}$ & $\mathbf{0 . 9 4 3 ^ { * }}$ & $\mathbf{0 . 8 9 0 ^ { * }}$ & $\mathbf{0 . 9 4 3 ^ { * }}$ & 1 & & & & & & & \\
\hline $\mathrm{Zn}$ & 0.489 & 0.355 & 0.550 & 0.595 & 1 & & & & & & \\
\hline $\mathrm{Cu}$ & 0.404 & 0.285 & 0.408 & 0.428 & 0.796 & 1 & & & & & \\
\hline $\mathrm{Ti}$ & -0.499 & -0.593 & $-0,471$ & -0.386 & -0.001 & 0.0095 & 1 & & & & \\
\hline $\mathrm{Pb}$ & -0.568 & -0.203 & -0.381 & -0.601 & -0.570 & -0.386 & -0.596 & 1 & & & \\
\hline $\mathrm{Rb}$ & -0.583 & -0.595 & -0.556 & -0.518 & -0.200 & -0.241 & 0.435 & 0.116 & 1 & & \\
\hline $\mathrm{Si}$ & -0.796 & -0.837 & -0.907 & $-0,803$ & -0.419 & -0.254 & 0.658 & 0.379 & 0.501 & 1 & \\
\hline $\mathrm{Al}$ & -0.835 & -0.806 & -0.850 & -0.777 & -0.334 & -0.140 & 0.617 & 0.566 & 0.620 & $\mathbf{0 . 9 4 4}$ & 1 \\
\hline
\end{tabular}

* Correlation is significant at the 0.05 level 
Therefore, the railway ballast can be determined as a significant source of $\mathrm{Cu}$. The highest $\mathrm{Cu}$ content in the railway stones 44 times exceeded the background concentration of $\mathrm{Cu}$ in soil $(20 \mathrm{mg} / \mathrm{kg})$. The content of $\mathrm{Cu}$ is not correlated with that of iron $(r=0.404)$, although $\mathrm{Cu}$ is an alloying metal. It can be explained by the fact that this metal has two completely different sources. The first and main source of the $\mathrm{Cu}$ emission (on the electrified railways) is considered to be the friction in the "pantographcontact wire" system. The other is the abrasion of brakes and rails. [Burkhardt et al., 2008; Liu et al, 2009; Malawska \& Wiołkomirski, 2001; Mazur et al., 2013; Wiłkomirski et al., 2011]. In addition, Šeda et al. [2017] found that the $\mathrm{Cu}$ pollution sources were wooden and ferroconcrete sleepers.

Chromium (Cr). The $\mathrm{Cr}$ concentration was below the limit of detection only in sample № 8 from track 1. Its content varied from $54.41 \pm 25.08$ $\mathrm{ppm}$ to $467.88 \pm 61.71 \mathrm{ppm}$. The mean value for chromium was $277.93 \pm 129.21 \mathrm{ppm}$, which exceeded the background value in soil 27.8 times, while the highest $\mathrm{Cr}$ content exceeded the background concentration 46.8 times. One of the $\mathrm{Cr}$ sources on railways is the railway ballast, which was proven by the obtained data. Another source of the $\mathrm{Cr}$ formation on railways involves the friction processes. The amount of the chromium emission $(960 \mathrm{~g} / \mathrm{km})$ ranked fifth after that of $\mathrm{Fe}$, $\mathrm{Cu}, \mathrm{Zn}$ and $\mathrm{Mn}$ on the Swiss Federal Railways [Burkhardt et al., 2008].

Nickel (Ni). Ni was not detected in two samples. The lowest content of this metal was $42.97 \pm 26.04 \mathrm{ppm}$ and the highest one $407.16 \pm 46.58 \mathrm{ppm}$. The mean value for the nickel content in the stones was $227.83 \pm 120.89$ ppm, which 22.8 times exceeded the background value in soil. The railway ballast can be classified as a source of $\mathrm{Ni}$. The sources of the $\mathrm{Ni}$ introduction on railways are freight loss, namely the leakage of oil and oil-products, as well as the friction of metal units, wheels, the fuel and coal combustion [Burkhardt et al., 2008; Mazur et al., 2013; Zelenko \& Samarska, 2014].

According to the absolute content of HMs in the ballast layer, they can be arranged in the following sequence: $\mathrm{Fe}>\mathrm{Mn}>\mathrm{Cu}>\mathrm{Cr}>\mathrm{Ni}$ $>\mathrm{Zn}>\mathrm{Pb}>$ As. The obtained results can be a framework for the development of methods for cleaning the ballast layer from HMs.

\section{Heavy metal content in railway stones after washing}

It should be noted that this study considered railway ballast as both primary and secondary source of HMs. Railway ballast itself contains a lot of HMs and some of them at significant concentrations ( $\mathrm{Fe}, \mathrm{Mn}, \mathrm{Cu}$ and $\mathrm{Cr}$ ). However, at the same time, it accumulates the pollutants resulting from the railway operation, especially, freight losses. For example, the total amount of losses during the transportation of mineral fertilizers in bulk in covered cars reaches up to $8 \%$, in gondola cars up to $28 \%$. When transported in multi-purpose cars, up to $7 \%$ of ore and $3 \%$ of cement are lost annually [Kazantsev, 2015]. According to the statistics, 312.9 million tons of different freight was carried by railways in 2019 , among them:

- 40.0 MT of coal (42.7 MT in 2018);

- 4.3 MT of coke (4.9 MT in 2018);

- 3.3 MT of crude oil and petroleum products (3.5 MT in 2018);

- $68.3 \mathrm{MT}$ of iron and manganese ores (66.5 MT in 2018);

- 19.1 MT of ferrous metals (20.1 MT in 2018);

- 2.4 MT of ferrous scrap metals (3.0 MT in 2018);

- 1.0 MT of timber freight (2.4 MT in 2018);

- 4.4 MT of chemical and mineral fertilizers (3.4 MT in 2018);

- 39.8 MT of grain and grinding products (32.9 MT in 2018);

- 5.4 MT of cement (5.7 MT in 2018);

- 29.1 MT of engineering materials (35.9 MT in 2018);

- 45.5 MT of other freight (46.6 MT in 2018).

The major part of this freight contains HMs, released into the environment due to the significant rail car wear, which is more than $90 \%$.

The appearance of the new and investigated ballast stones is completely different. The contaminated ballast is covered with the dust containing a lot of HMs and sometimes with oil-products. Figure 5 shows the above-mentioned difference.

A thick layer of the metal dust has resulted from many years of the railway operations (the age of the ballast is 12 years). This dust is not removed by the rain or wind. Moreover, it was very hard to clean the samples from the dust using the detergent agent and dishwashing sponge.

Table 5 presents the results before and after washing the samples. 
a)

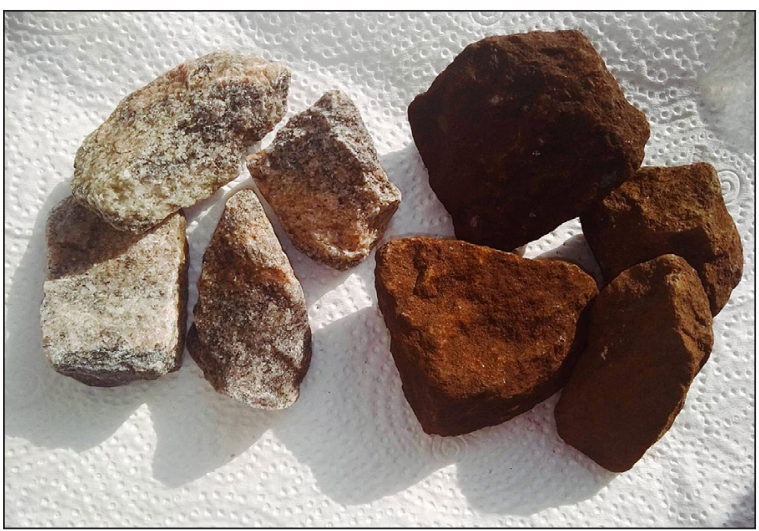

b)

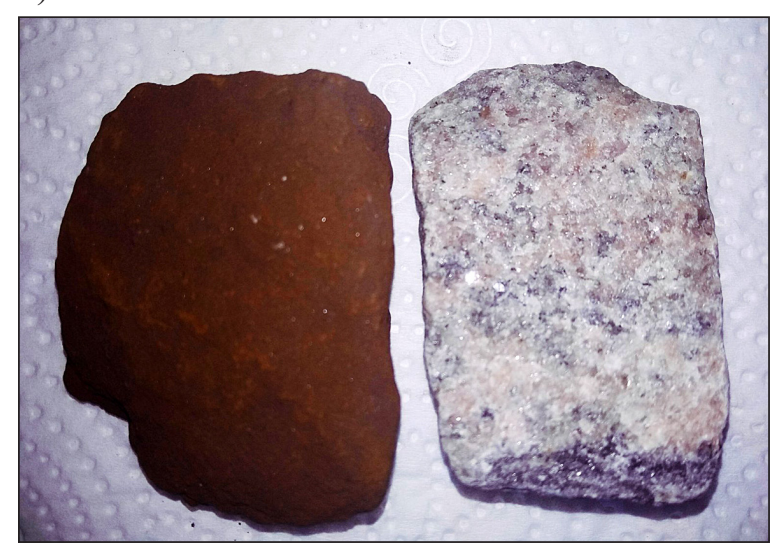

Fig. 5. The appearance of the new and investigated railway ballast stones

After washing the samples, the content of Fe, $\mathrm{Mn}, \mathrm{Ni}, \mathrm{Cr}, \mathrm{Cu}, \mathrm{Zn}$ and As decreased since a thick layer of the metal dust was removed from the stone surface.

The iron content significantly declined by $76.8 \%$ for sample 1 , by $76.1 \%$ for sample 2 and $79.5 \%$ for sample 3 , which proves that the railway operations are a cause of the environmental pollution with iron, which can be dangerous as iron oxides and chelates sorb other more toxic HMs and contribute to their accumulation in soil. Lorenzo et al. [2006] found that the emissions of the railway lines were dominated by the 'iron' particles, which contributed $2.9 \mu \mathrm{g} / \mathrm{m}^{3}$ or $67 \%$ to the railway related $\mathrm{PM}_{10}$. The Mn content was also significantly reduced by $74.2 \%$ for sample 1, by $72.8 \%$ for sample 2 and $73.9 \%$ for sample 3 , which correlates with the Fe results. The reduction of the $\mathrm{Cr}$ concentration was $69.7 \%$ (1),
$62.1 \%$ (2) and $75.8 \%$ (3). The copper content was reduced by $91.7 \%(1), 87.2 \%(2)$ and $62.1 \%$ (3), which demonstrates that this metal can result from freight losses and friction process. The sampling location is a zone of intensive working the brakes, which contain copper. The emission of the dust containing $\mathrm{Cu}$ due to the contact wire abrasion can also contribute to this pollution, but taking into account the height of the contact system, this emission spreads at longer distances. According to Liu et al. [2009], Cu showed further dispersion distance of $25 \mathrm{~m}$ due to a main $\mathrm{Cu}$ emission source, the head-over traction cable, being located higher than any other metal emission source (wheels and tracks).

Di Palma \& Petrucci [2014] showed that only a slight release of $\mathrm{Cu}$ and $\mathrm{Zn}$ was observed for the uncontaminated ballast stones. The Cd concentration in the leachate was always below the

Table 5. The heavy metal content in the railway stones before and after washing, ppm

\begin{tabular}{|c|c|c|c|c|c|c|}
\hline \multicolumn{7}{|c|}{ Sample 1, track 1, before washing } \\
\hline As & $\mathrm{Cr}$ & $\mathrm{Cu}$ & $\mathrm{Fe}$ & $\mathrm{Mn}$ & $\mathrm{Ni}$ & $\mathrm{Zn}$ \\
\hline $25.83 \pm 6.91$ & $\begin{array}{l}372.67 \\
\pm 49.68\end{array}$ & $\begin{array}{l}240.32 \\
\pm 28.97\end{array}$ & $\begin{array}{c}259782.14 \\
\pm 1885.68\end{array}$ & $\begin{array}{c}1987.2 \\
\pm 123.73\end{array}$ & $\begin{array}{c}351.23 \pm \\
46.72\end{array}$ & $\begin{array}{r}48.45 \\
\pm 12.96\end{array}$ \\
\hline \multicolumn{7}{|c|}{ Sample 1, track 1, after washing } \\
\hline $\begin{array}{r}6.55 \\
\pm 3.32 \\
\end{array}$ & $\begin{array}{c}112.92 \pm \\
27.99\end{array}$ & $\begin{array}{c}19.96 \pm \\
12.39\end{array}$ & $\begin{array}{c}60242.09 \pm \\
452.93\end{array}$ & $\begin{array}{c}513.08 \pm \\
74.4\end{array}$ & $\begin{array}{c}54.78 \pm \\
25.76\end{array}$ & $\begin{array}{c}45.5 \pm \\
8.28 \\
\end{array}$ \\
\hline \multicolumn{7}{|c|}{ Sample 2, track 1, before washing } \\
\hline $\begin{array}{r}15.39 \\
\pm 4.53 \\
\end{array}$ & $\begin{array}{l}306.86 \\
\pm 40.36 \\
\end{array}$ & $\begin{array}{l}184.97 \\
\pm 21.05 \\
\end{array}$ & $\begin{array}{c}166049.73 \\
\pm 1078.59 \\
\end{array}$ & $\begin{array}{c}1292.23 \\
\pm 96.74 \\
\end{array}$ & $\begin{array}{l}269.47 \\
\pm 34.09 \\
\end{array}$ & $\begin{array}{c}36.02 \\
\pm 9.5 \\
\end{array}$ \\
\hline \multicolumn{7}{|c|}{ Sample 2, track 1 , after washing } \\
\hline$<$ LOD & $\begin{array}{r}116.27 \\
\pm 23.75\end{array}$ & $\begin{array}{c}23.61 \\
\pm 12.23\end{array}$ & $\begin{array}{c}39609.04 \\
\pm 343.01\end{array}$ & $\begin{array}{l}351.45 \\
\pm 70.61 \\
\end{array}$ & $<$ LOD & $\begin{array}{l}29.59 \\
\pm 7.33\end{array}$ \\
\hline \multicolumn{7}{|c|}{ Sample 3 , track 1 , before washing } \\
\hline $\begin{array}{r}18,03 \\
\pm 5,26 \\
\end{array}$ & $\begin{array}{c}332.88 \pm \\
43.25\end{array}$ & $\begin{array}{r}117.42 \\
\pm 19.33 \\
\end{array}$ & $\begin{array}{c}158418.45 \\
\pm 1054.45\end{array}$ & $\begin{array}{l}1221.03 \\
\pm 97.55\end{array}$ & $\begin{array}{l}280.52 \\
\pm 35.13 \\
\end{array}$ & $\begin{array}{c}48.6 \\
\pm 10.23 \\
\end{array}$ \\
\hline \multicolumn{7}{|c|}{ Sample 3, track 1, after washing } \\
\hline$<$ LOD & $\begin{array}{c}80.4 \\
\pm 23.49\end{array}$ & $\begin{array}{c}44.53 \\
\pm 12.79\end{array}$ & $\begin{array}{c}32484.32 \\
\pm 304.7\end{array}$ & $\begin{array}{l}318.72 \\
\pm 70.06\end{array}$ & $<$ LOD & $\begin{array}{l}34.42 \\
\pm 7.52\end{array}$ \\
\hline
\end{tabular}


detection limits. These results are similar to ours after cleaning the stones.

\section{Heavy metal content in herbicides}

The content of $\mathrm{Cd}, \mathrm{Co}, \mathrm{Cr}, \mathrm{Cu}, \mathrm{Fe}, \mathrm{Mn}, \mathrm{Ni}, \mathrm{Pb}$ and $\mathrm{Zn}$ was detected in all the investigated herbicides (the description of the herbicides is presented in Table 1). Table 6 presents the HM content in the investigated herbicides

All the samples contained $\mathrm{Cd}$ at the concentration less than $0.3 \mathrm{mg} / \mathrm{L}$. Cadmium is a nonessential element that negatively affects the plant growth and development. It is one of the most dangerous metals due to its high mobility and its effects on plants begin to appear even at a small concentration [Benavides et al., 2005]. Therefore, $\mathrm{Cd}$ can be added intentionally to enhance the herbicide effect. The highest $\mathrm{Cd}$ concentration was found in herbicide 5 ("Anti field bindweed"), $0.25 \mathrm{mg} / \mathrm{L}$, the lowest Cd concentration - in herbicide 1 ("Round up"), $0.1 \mathrm{mg} / \mathrm{L}$. For comparison, the Ukrainian maximum permissible concentration (hereafter - MPC) of $\mathrm{Cd}$ is $0.001 \mathrm{mg} / \mathrm{L}$ for drinking water and $0.005 \mathrm{mg} / \mathrm{L}$ for fishery water.

It should be noted that there are no regulatory documents for the levels of HMs in herbicides. Moreover, their ingredients are confidential business information [Defarge et al., 2018].

Co was detected in each sample at the concentration less than $0.6 \mathrm{mg} / \mathrm{L}$. Herbicide 5 was characterized by the highest Co content, $0.58 \mathrm{mg} / \mathrm{L}$. The lowest content of Co was found in herbicide 3 ("Tornado Forte"), $0.01 \mathrm{mg} / \mathrm{L}$. Cobalt is known to be an essential component of several enzymes and co-enzymes. Consequently, the Co present in the herbicides can result from casual contamination. The cobalt toxicity for humans and plants has been documented [Leyssens et al., 2017; Palit et al., 1994]. The Ukrainian MPC of Co is
$0.1 \mathrm{mg} / \mathrm{L}$ for drinking water and $0.005 \mathrm{mg} / \mathrm{L}$ for fishery water.

The four samples contained $\mathrm{Cr}$ at the concentration less than $0.6 \mathrm{mg} / \mathrm{L}$, except herbicide 5 , which contained $1.79 \mathrm{mg} / \mathrm{L}$ of Cr. Such a significant amount of $\mathrm{Cr}$ can be related to its toxic properties. $\mathrm{Cr}$ causes oxidative stress, damages membrane lipids and DNA. Cr may even cause the death of plant species. Few plant species are able to accumulate high amount of $\mathrm{Cr}$ without being damaged [Singh et al., 2013]. Cr was possibly added to herbicide 5 to increase its influence on plants. There are the MPC for different oxidation degrees in Ukraine: Cr III for drinking water $0.5 \mathrm{mg} / \mathrm{L}$, for fishery water $-0.005 \mathrm{mg} / \mathrm{L}$; Cr VI for drinking water $-0.05 \mathrm{mg} / \mathrm{L}$ and for fishery water $-0.001 \mathrm{mg} / \mathrm{L}$.

For all the herbicides, the copper content was less than $0.5 \mathrm{mg} / \mathrm{L}$. The MPC of $\mathrm{Cu}$ is $1 \mathrm{mg} / \mathrm{L}$ for drinking water and $0.005 \mathrm{mg} / \mathrm{L}$ for fishery water. At high concentration, $\mathrm{Cu}$ can become extremely toxic, causing such symptoms as chlorosis, necrosis, stunting, leaf discoloration and root growth inhibition [Yruela, 2005].

$\mathrm{Fe}$ was detected in all the herbicides. The lowest concentration was detected in herbicide $1-0.63 \mathrm{mg} / \mathrm{L}$. The MPC of Fe is $0.3 \mathrm{mg} / \mathrm{L}$ for drinking water and $0.1 \mathrm{mg} / \mathrm{L}$ for fishery water. The highest content of iron was detected in herbicide $2-10.47 \mathrm{mg} / \mathrm{L}$. In addition, sample 5 was characterized by the high Fe content, which can point up the fact that $\mathrm{Fe}$ was added intentionally. The ability of $\mathrm{Fe}$ to receive and donate electrons plays an important role in the electron transport chains of photosynthesis and respiration. However, this metal is highly reactive and toxic in high concentration. As a result of the Fenton reaction, hydroxyl radicals are released, which can damage lipids, proteins and DNA. [Connolly \& Guerinot, 2002].

Table 6. The concentrations of heavy metals in the herbicides

\begin{tabular}{|c|c|c|c|c|c|c|c|c|c|}
\hline \multirow{2}{*}{ Name } & \multicolumn{9}{|c|}{ Heavy metals, mg/L } \\
\cline { 2 - 11 } & $\mathrm{Cd}$ & $\mathrm{Co}$ & $\mathrm{Cr}$ & $\mathrm{Cu}$ & $\mathrm{Fe}$ & $\mathrm{Mn}$ & $\mathrm{Ni}$ & $\mathrm{Pb}$ & $\mathrm{Zn}$ \\
\hline Herbicide 1 & 0.1 & 0.28 & 0.05 & $<0.5$ & 0.63 & 0.08 & 0.66 & 2.05 & 5.47 \\
\hline Herbicide 2 & 0.16 & 0.79 & 0.59 & $<0.5$ & 10.47 & 0.09 & $<0.8$ & $<1$ & $<1$ \\
\hline Herbicide 3 & 0.12 & 0.01 & 0.11 & $<0.5$ & 2.88 & 0.12 & 0.65 & 1.93 & 4.07 \\
\hline Herbicide 4 & 0.15 & 0.03 & 0.17 & $<0.5$ & 4.33 & 0.05 & 0.32 & 1.29 & $<1$ \\
\hline Herbicide 5 & 0.25 & 0.58 & 1.79 & $<0.5$ & 8.93 & $<0.1$ & 2.1 & 3.25 & $<1$ \\
\hline MPC $_{\text {drinking water }}$ & 0.001 & 0.1 & $\begin{array}{c}0.5(\mathrm{III}) \\
0.05(\mathrm{VI})\end{array}$ & 1 & 0.3 & 0.1 & 0.1 & 0.03 & 1 \\
\hline $\mathrm{MPC}_{\text {fishery water }}$ & 0.005 & 0.005 & $\begin{array}{c}0.005(\mathrm{III}) \\
0.001(\mathrm{VI})\end{array}$ & 0.005 & 0.1 & 0.01 & 0.01 & 0.1 & 0.01 \\
\hline
\end{tabular}


All the herbicides contained lead. The lead content in herbicide 2 was less than $1 \mathrm{mg} / \mathrm{L}$. The highest concentration of $\mathrm{Pb}$ was detected in Anti field bindweed, which has the most complicated content and is used for persistent weed control. Lead significantly affects normal plant metabolism, morph-physiological features and crop growth and productivity. It often results in diminished growth, cellular structure and ion homeostasis deformation, reductions in chlorophyll biosynthesis, hormonal misbalance and induces over-production of reactive oxygen species in plants [Ashraf et al., 2017]. The MPC of $\mathrm{Pb}$ is $0.03 \mathrm{mg} / \mathrm{L}$ for drinking water and $0.1 \mathrm{mg} / \mathrm{L}$ for fishery water.

$\mathrm{Ni}$ was detected in all the herbicides. The highest level of Ni was found in herbicide 5 $2.1 \mathrm{mg} / \mathrm{L}$, which 21 times exceeded the MPC for drinking water and 210 times for fishery water. Like other HMs, the excess concentration of $\mathrm{Ni}$ in plants causes chlorosis and necrosis. Elevated $\mathrm{Ni}$ concentration can inhibit the cell division in root meristems in the non-tolerant plants and decrease the plant growth [Bhalerao et al, 2015]. Nickel is often contained in oil-products, some types of which are used as formulations in herbicides, for example polyoxyethylenamines [Defarge et al., 2018].

Three herbicides contained $\mathrm{Zn}$ at the concentration less than $1 \mathrm{mg} / \mathrm{L}$. The concentration of $\mathrm{Zn}$ in herbicide 1 was $5.47 \mathrm{mg} / \mathrm{L}$, in herbicide $3-4.07 \mathrm{mg} / \mathrm{L}$. Most plants contain from 30 to $100 \mathrm{mg} \mathrm{Zn/kg}$ dry matter, whereas the content above $300 \mathrm{mg} / \mathrm{kg}$ is generally toxic [Noulas et al., 2018]. Therefore, the zinc content detected in the herbicides cannot cause plant death itself, but in combination with active ingredients and other HMs, such low concentration of Zn may increase the herbicide effect. For comparison, the MPC of $\mathrm{Zn}$ is $1 \mathrm{mg} / \mathrm{L}$ for drinking water and $0.01 \mathrm{mg} / \mathrm{L}$ for fishery water.

Manganese was detected in all the herbicides, but at low concentration. This metal is unlikely to be added intentionally. $\mathrm{Mn}$ is an integral microelement and like any other element, it can be toxic at high concentration, but not at $0.1 \mathrm{mg} / \mathrm{L}$ in herbicides. For comparison, the MPC of Mn is $0.1 \mathrm{mg} / \mathrm{L}$ for drinking water and $0.01 \mathrm{mg} / \mathrm{L}$ for fishery water reservoirs.

The herbicides can be determined as a negligible source of HMs. Moreover, herbicides are always diluted prior to use, according to the instruction. Thus, the concentration of HMs in the solution significantly decreases. However, HMs together with active ingredients, are a solid reason for concern. Currently, there are a lot of ecologically-friendly methods for weed control on railways at our disposal: constructional, mechanical and biological ones. The constructional methods include different types of weed barriers (bituminous, porous concrete and lateral barriers), insertion of foils and verge design. The mechanical measures involve ballast cleaning and vacuuming, machine and manual weeding as well as moving. Finally, the biological methods are greening (deliberate sowing the desired plants to protect soil from erosion and weathering), creating grassplots along railways, as well as mapping plant species and soil types.

\section{CONCLUSION}

To sum up, the ballast layer contained insufficient quantity of Cd, Co, Mo, Pd, Sn and W for detection. Only in several samples, $\mathrm{Pb}$ and $\mathrm{As}$ were detected at the low concentration of less than $35 \mathrm{ppm}$. Therefore, the contaminated railway ballast layer cannot be identified as a source of $\mathrm{Cd}, \mathrm{Co}, \mathrm{Mo}, \mathrm{Pd}, \mathrm{Sn}, \mathrm{W}, \mathrm{Pb}$ and As.

The research results showed that the investigated railway ballast is a significant source of $\mathrm{Fe}, \mathrm{Mn}, \mathrm{Cu}, \mathrm{Cr}$ and Ni. According to the absolute content of HMs in the ballast layer, they can be arranged in the following sequence: $\mathrm{Fe}>\mathrm{Mn}>\mathrm{Cu}$ $>\mathrm{Cr}>\mathrm{Ni}>\mathrm{Zn}>\mathrm{Pb}>\mathrm{As}$. The content of $\mathrm{Fe}$ was strongly correlated with that of $\mathrm{Ni}(\mathrm{r}=0.972), \mathrm{Cr}$ $(r=0.954)$ and $\mathrm{Mn}(\mathrm{r}=0.943)$ All the metals are components of the railway steel. Therefore, their source is the abrasion of rails and wheels.

As for $\mathrm{Zn}$, its content in the stones changed from $19.64 \pm 6.9 \mathrm{ppm}$ to $188.59 \pm 18.76 \mathrm{ppm}$. It was not detected only in two samples. After washing the stones, the zinc content did not change substantially; it remained within the measurement limiting accuracy. In this case, the railway ballast can be considered as a moderate source of zinc itself.

All the herbicides contained $\mathrm{Cd}, \mathrm{Co}, \mathrm{Cr}, \mathrm{Cu}$, $\mathrm{Fe}, \mathrm{Mn}, \mathrm{Ni}, \mathrm{Pb}$ and $\mathrm{Zn}$. It is hard enough to identify if HMs are added deliberately as nanoparticles or they result from unintentional pollution, during the manufacturing process. The highest content of $\mathrm{Cd}, \mathrm{Cr}, \mathrm{Ni}, \mathrm{Pb}$ was detected in herbicide 5 ("Anti field bindweed"), which can be related to its complicated composition. Compared to the 
HM content in the ballast stones, the herbicides can be considered an insignificant source of these pollutants.

\section{Acknowledgements}

The authors express appreciation to German Academic Exchange Service (DAAD, Deutscher Academischer Austauschdienst) for the opportunity to conduct the above presented research within the framework of the project "EcoMining: Development of Integrated PhD Program for Sustainable Mining \& Environmental Activities" and TU Bergakademie Freiberg.

We personally thank Prof. Dr. Hermann Heilmeier, Dipl.-Ing. (FH) Marlies Grimmer, M.Sc. Juliane Günther and B.Sc. Viktoria Mezovska for their professional assistance and support in this research work.

\section{REFERENCES}

1. Ascensão F., Capinha C. 2017. Aliens on the Move: Transportation Networks and Non-native Species. In: Borda-de-Água L., Barrientos R., Beja P., Pereira H. (eds) Railway Ecology. Springer, Cham.

2. Ashraf U., Kanu A. S., Deng Q., Mo Z., Pan S., Tian H., \& Tang X. 2017. Lead (Pb) Toxicity; PhysioBiochemical Mechanisms, Grain Yield, Quality, and $\mathrm{Pb}$ Distribution Proportions in Scented Rice. Frontiers in Plant Science, 8, 259.

3. Balaram V., Dharmendra V., Roy P., Taylor C., Kamala, C. T., Satyanarayanan M., et al. 2014. Analysis of geochemical samples by microwave plasmaAES. Atomic Spectroscopy, 35(2), 65-78

4. Barrientos R., Ascensão F., Beja P., Pereira H. M. \& Borda-de-Agua L. 2019. Railway ecology vs. road ecology: similarities and differences. European Journal of Wildlife Research, 65, 12.

5. Benavides M. P., Gallego S. M., \& Tomaro M. L. 2005. Cadmium toxicity in plants. Brazilian Journal of Plant Physiology, 17(1), 21-34.

6. Bhalerao S.A., Sharma A.S., \& Poojari A. C. 2015. Toxicity of Nickel in Plants. International journal of pure \& applied bioscience, 3(2), 345-355.

7. Bobryk N. 2015. Spreading and accumulation of heavy metals in soils of railway-side areas. Visnyk of Dnipropetrovsk University. Biology, ecology, 23(2), 183-189. (in Ukranian)

8. Borda-de-Água L., Barrientos R., Beja P., Pereira H.M. 2017. Railway Ecology. In: Borda-de-Água L., Barrientos R., Beja P., Pereira H. (eds) Railway Ecology. Springer, Cham.
9. Bukowiecki N., Gehrig R., Hill M., Lienemann P., Zwicky C.N., Buchmann B., et al. 2007. Iron, manganese and copper emitted by cargo and passenger trains in Zürich (Switzerland): size-segregated mass concentrations in ambient air. Atmospheric Environment, 41(4), 878-889.

10. Burkhardt M., Rossi L., \& Boller M. 2008. Diffuse release of environmental hazards by railways. Desalination, 226(1-3), 106-113.

11. Chen Z., Wang K., Ai Y. W., Li W., Gao H., \& Fang C. 2014. The effects of railway transportation on the enrichment of heavy metals in the artificial soil on railway cut slopes. Environmental Monitoring and Assessment, 186(2), 1039-1049.

12. Connolly E.L., \& Guerinot M.L. 2002. Iron stress in plants. Genome Biology, 3(8), reviews 1024.1-1024.4.

13. Defarge N., Spiroux de Vendômois J., \& Séralin G. E. 2018. Toxicity of formulants and heavy metals in glyphosate-based herbicides and other pesticides. Toxicology Reports, 5, 156-163.

14. Di Palma L., \& Petrucci E. 2014. Treatment and recovery of contaminated railway ballast. Turkish Journal of Engineering \& Environmental Sciences, 38, 248-255. https://doi.org/10.3906/muh-1404-9

15. Donati G.L., Amais R.S., Schiavo, D., \& Nobrega J.A.N. 2013. Determination of $\mathrm{Cr}, \mathrm{Ni}, \mathrm{Pb}$ and $\mathrm{V}$ in gasoline and ethanol fuel by microwave plasma optical emission spectrometry. Journal of Analytical Atomic Spectrometry, 28(5), 755-759.

16. Dzierżanowski K. \& Gawroński S. W. 2012. Heavy metal concentration in plants growing on the vicinity of railroad tracks: a pilot study. Challenges of Modern Technology, 3(1), 42-45.

17. Gil K. \& Im J. 2015. Analysis of non-point source characteristics of heavy metals and oil and grease at railway bridge area with various land uses. Desalination and Water Treatment, 54(13), 3721-3727.

18. Jaishankar M., Tseten T., Anbalagan N., Mathew B. B., \& Beeregowda K. N. 2014. Toxicity, mechanism and health effects of some heavy metals. Interdisciplinary toxicology, 7(2), 60-72.

19. Kazantsev I.V. 2015. Rail transport is a source of soil contamination with heavy metals. Samarskiy nauchnyiy vestnik, 2(4), 94-96. (in Russian).

20. Leyssens L., Vinck B., Van Der Straeten C., Wuyts F. \& Maes L. 2017. Cobalt toxicity in humans-A review of the potential sources and systemic health effects. Toxicology, 387, 43-56.

21. Li Y., Ye F., Wang A., Wang D., Yang B., Zheng Q., et al. 2016. Chronic arsenic poisoning probably caused by arsenic-based pesticides: findings from an investigation study of a household. International Journal of Environmental Research and Public Health, 13(1), 133. 
22. Liu H., Chen L.P., Ai Y. W., Yang X., Yu Y.H., Zuo Y.B. \& Fu G.Y. 2009. Heavy metal contamination in soil alongside mountain railway in Sichuan, China. Environmental Monitoring and Assessment, 152(1-4), 25-33. https://doi.org/10.1007/ s10661-008-0293-7

23. Lorenzo, R., Kaegi, R., Gehrig, R., \& Grobéty, B. 2006. Particle emissions of a railway line determined by detailed single particle analysis. Atmospheric Environment, 40(40), 7831-7841.

24. Lucas P.S., de Carvalho R.G., Grilo C. 2017. Railway Disturbances on Wildlife: Types, Effects, and Mitigation Measures. In: Borda-de-Água L., Barrientos R., Beja P., Pereira H. (eds) Railway Ecology. Springer, Cham.

25. Ma J.H., Chu C.J., Li J. \& Song B. 2009. Heavy Metal Pollution in Soils on Railroad Side of Zhengzhou-Putian Section of Longxi-Haizhou Railroad, China. Pedosphere, 19(1), 121-128.

26. Malawska M., \& Wiołkomirski B. 2001. An Analysis of Soil and Plant (Taraxacum Officinale) Contamination with Heavy Metals and Polycyclic Aromatic Hydrocarbons (PAHs) In the Area of the Railway Junction Iława Główna, Poland. Water, Air, and Soil Pollution, 127(1-4), 339-349.

27. Malawska M., \& Wiłkomirski B. 2000. Soil and plant contamination with heavy metals in the area of the old railway junction Tarnowskie Góry and near two main railway routes. Rocz Panstw Zakl Hig, 51(3), 259-67.

28. Mazur Z., Radziemska M., Maczuga O., \& Makuch A. 2013. Heavy metal concentrations in soil and moss (Pleurozium schreberi) near railroad lines in Olsztyn (Poland). Fresenius

29. Meng X., Ai Y., Li R. \& Zhang W. 2018. Effects of heavy metal pollution on enzyme activities in railway cut slope soils. Environmental Monitoring and Assessment, 190(4), 197.

30. Mętrak M., Chmielewska M., Sudnik-Wójcikowska B., Wiłkomirski B., Staszewski T., \& SuskaMalawska M. 2015. Does the Function of Railway Infrastructure Determine Qualitative and Quantitative Composition of Contaminants (PAHs, Heavy Metals) in Soil and Plant Biomass? Water Air Soil Pollution, 226(8), 1-12 (253).

31. Mohsen M., Ahmed M.B., \& Zhou J.L. 2018. Particulate matter concentrations and heavy metal contamination levels in the railway transport system of Sydney, Australia. Transportation Research Part D: Transport and Environment, 62, 112-124.

32. Murphy E.A. \& Aucott M. 1998. An assessment of the amounts of arsenical pesticides used historically in a geographical area. Science of The Total Environment, 218(2-3), 89-101.

33. Noulas C., Tziouvalekas M., \& Karyotis T. 2018.
Zinc in soils, water and food crops. Journal of Trace Elements in Medicine and Biology, 49, 252-260.

34. Palit S., Sharma A. \& Talukder G. 1994. Effects of cobalt on plants. The Botanical Review, 60(2), 149-181.

35. Plakhotnik V.N., Onyshchenko J.V. \& Yaryshkina L.A. 2005. The environmental impacts of railway transportation in the Ukraine. Transportation Research Part D: Transport and Environment, 10(3), 263-268.

36. Popp J.N., \& Boyle S.P. 2017. Railway ecology: Underrepresented in science? Basic and Applied Ecology, 19, 84-93.

37. Ramwell C.T., Heather A.I. \& Shepherd A.J. 2004. Herbicide loss following application to a railway. Pest Management Science, 60(6), 556-564.

38. Samarska A.V. \& Zelenko Yu. V. 2018a. Assessment of the railway influence on the heavy metal accumulation in soil. Science and Transport Progress. Bulletin of Dnipropetrovsk National University of Railway Transport, 4(76), 25-35.

39. Samarska A.V. \& Zelenko Yu. V. 2018b. The patterns of spreading and accumulating heavy metals in the railway infrastructure soils. The scientific-practical journal Railway transport of Ukraine, 3(128), 13-21. (in Ukrainian)

40. SBB 2001. Vegetation Control on Railway Tracks and Grounds. Swiss Railroad.

41. Schweinsberg F., Abke W., Rieth K., Rohmann U. \& Zullei-Seibert N. 1999. Herbicide use on railway tracks for safety reasons in Germany? Toxicology Letters, 107(1-3), 201-205.

42. Šeda M., Šíma J., Volavka T., \& Vondruška J. 2017. Contamination of soils with $\mathrm{Cu}, \mathrm{Na}$ and $\mathrm{Hg}$ due to the highway and railway transport. Eurasian Journal of Soil Science, 6(1), 59-64.

43. Singh H.P., Mahajan P., Kaur S., Batish D.R., \& Kohli R.K. 2013. Chromium toxicity and tolerance in plants. Environmental Chemistry Letters, 11(3), 229-254.

44. Skark C., Zullei-Seibert N., Willme U., Gatzemann U. \& Schlett C. 2004. Contribution of non-agricultural pesticides to pesticide load in surface water. Pest Management Science, 60(6), 525-530.

45. Staszewski T., Malawska, M., Studnik-Wójcikowska B., Galera H., \& Wiłkomirski B. 2015. Soil and plants contamination with selected heavy metals in the area of a railway junction. Archives of Environmental Protection, 41(1), 35-42.

46. Stojic N., Pucarevic M., \& Stojic G. 2017. Railway transportation as a source of soil pollution. Transportation Research Part D: Transport and Environment, 57, 124-129.

47. Oyedotun T.D.T. 2018. X-Ray Fluorescence (XRF) in the Investigation of the Composition of Earth 
Materials: A Review and an Overview. Geology, Ecology, and Landscapes, 2, 148-154.

48. Thommesen J., Duijm N.J. \& Andersen H.B. 2014. Management of low adhesion on railway tracks in European countries. DTU Management Engineering.

49. Vudagandla S., Siva Kumar N., Dharmendra V., Asif M., Balaram V., Zhengxu H., \& Zhen Z. 2017. Determination of Boron, Phosphorus, and Molybdenum Content in Biosludge Samples by Microwave Plasma Atomic Emission Spectrometry (MP-AES). Applied Science, 7(3), 264.

50. Wan D., Han Z., Yang J., Yang G., \& Liu X. 2016. Heavy Metal Pollution in Settled Dust Associated with Different Urban Functional Areas in a Heavily Air-Polluted City in North China. International Journal of Environmental Research and Public Health, 13(11), 1119.

51. Weltje G.J., \& Tjallingii R. 2008. Calibration of XRF core scanners for quantitative geochemical logging of sediment cores: Theory and application. Earth Planet Science Letters, 274(3-4), 423-438.

52. Wierzbicka M., Bemowska-Kałabun O. \& Gworek B. 2015. Multidimensional evaluation of soil pollution from railway tracks. Ecotoxicology, 24(4), 805-822.

53. Wiłkomirski B., Galera H., Sudnik-Wójcikowska B., Staszewski T. \& Malawska M. 2012. Railway Tracks - Habitat Conditions, Contamination, Floristic Settlement - A Review. Environment and Natural
Resources Research, 2(1), 86-95.

54. Wiłkomirski B., Sudnik-Wójcikowska B., Galera H., Wierzbicka M. \& Malawska M. 2011. Railway transportation as a serious source of organic and inorganic pollution. Water Air Soil Pollution, 218(1-4), 333-345.

55. Wiłkomirski B., Suska-Malawska M., SudnikWójcikowska B., \& Staszewski T. 2013. The selected trace elements in soil of railway stations in north-eastern Poland. Rocznik Świętokrzyski. Ser. B - Nauki Przyr, 34, 171-180.

56. Yruela I. 2005. Copper in plants. Brazilian Journal of Plant Physiology, 17(1), 145-156.

57. Zelenko Yu., Myamlin S. \& Sandovskiy M. 2014. Scientific foundation of management of the environmental safety of oil product turnover in railway transport. Dnipropetrovsk: Lithograph.

58. Zelenko Yu. V. \& Samarska A.V. 2014. The problem of heavy metal pollution of the railway precinct. The scientific-practical journal Railway transport of Ukraine, 5(108), 51-53 (in Ukrainian).

59. Zhang H., Wang Z., Zhang Y. \& Hu Z. 2012. The effects of the Qinghai-Tibet railway on heavy metals enrichment in soils. Science of the Total Environment, 439, 240-248.

60. Zhang H., Zhang Y., Wang Z. \& Ding M. 2013. Heavy metal enrichment in the soil along the DelhiUlan section of the Qinghai-Tibet railway in China. Environmental Monitoring and Assessment, 185, 5435-5447. 